hydrogen in the first phase and carbon dioxide and methane in the second phase. Only a small amount of gaseous nitrogen was formed. Other experiments showed that by a secondary reaction under swamp soil conditions, carbon dioxide and hydrogen are recombined by bacterial agencies with the formation of organic matter and even methane. Hence the important conclusion was reached that the gases actually found in swamp soils are a residue of the gases produced in the primary fermentation, thus providing a rational explanation for the peculiar composition of the soil gas.

The gas evolved from the surface of swamp soils was found to consist mainly of oxygen and nitrogen. This gas is entirely distinct from the gases in the soil, and the soil gases do not normally escape from the surface. The evolution of oxygen at the surface was shown to be the work of a mixed film composed of certain bacteria, diatoms and algæ. The bacteria were isolated and characterized and shown to have the power of oxidizing methane and hydrogen. The photosynthetic utilization of carbon dioxide with liberation of oxygen by the film was proved, and it was shown that the development of oxygen was dependent upon the supply of methane and carbon dioxide from the soil gases.

From these and other inquiries, Harrison demon. strated that an important indirect manurial effect of green manure is to aerate the soil water in this type of cultivation. Comparing cropped and uncropped soil, it was found, among other interesting facts, that cropping greatly increased the formation of gaseous nitrogen, especially during the later stages of growth. Evidence from numerous experiments showed that the extra nitrogen formed in cropped soils is derived from the fermentation of dead roots which accumulate as the plant grows. The nitrogen cycle did not seem favourable, and it is evident that Harrison was aiming at further work on this aspect of the subject, but at this stage he was appointed Imperial agricultural chemist and transferred to Pusa. The appointment was an honour and a call to greater responsibility. He had to abandon his work on rice, but he has left a contribution which is unique.

At Pusa, Harrison undertook inquiries into soil nitrates and phosphates and soil reaction. The work on the influence of calcium carbonate on the penetration of certain phosphatic manures into the soil yielded notable information. Eventually administrative duties filled more and more of his time. He was first appointed joint director of Pusa and later became head of the service as director and agricultural adviser to the Government of India, from which post he retired in 1931 .

\section{Dr. Panchanan Mitra}

Tre death occurred on July 25, after a short illness, of Dr. Panchanan Mitra, head of the Depart. ment of Anthropology of the University of Calcutta.

Panchanan Mitra, born in Caleutta on May 25, 1891 , was a member of a family already distinguished in the study of Indian history and culture. His grandfather, Raja Rajendra Lal Mitra, was the first Indian president of the Asiatic Society of Bengal. After a distinguished career at the University of Calcutta and four years as a lecturer in English, Panchanan Mitra in 1919 was awarded the Premchand Raichand Scholarship of his university for a thesis afterwards (1923) published under the title "Prehistoric India" ; and in the same year was appointed to the staff of the Department of Anthropology. of which he became head on the retirement of Diwan Bahadur Dr. Anantha Krishna Iyer in 1932. In 1929, at the instance of Dr. Craighill Handy, he was appointed to a fellowship of the Bernice P. Bishop Museum, Honolulu, and travelled extensively in Polynesia, collecting evidence bearing upon the problem of the influence of Indian cultural traits on Polynesia. His results are now on the point of publication. A period spent at Yale University working with Dr. Clark Wissler on distributional studies resulted in "A History of American Anthropology" (Calcutta, 1931), for which he was awarded a Ph.D. In 1931 also he visited Spain and southern France as a member of the American School of Archæology in France. Two years later he presided over the Anthropological Seation of the Indian Science Congress.

Dr. Mitra was not only himself a distinguished research worker, but he was also an organizer of research. He was responsible for the close conjunction of research in the laboratory and in the field, which is now an important feature in the work of his Department. His premature death is a great loss to anthropological studies in India.

\section{Prof. Eugene Lagrange}

EUGENE LAGRANGE, seismologist and emeritus professor of physics at the Ecole militaire at Brussels, died in that city on June 15 (Boll. Ital. Soc. Sism., 34 , I56 ; 1936). Born in 1855, he entered the Ecole militaire in 1873 and, after passing through its course, was appointed first as assistant professor, and then as professor, of physics, an office that he held until his retirement in 1907. In 1898, he spent some time in Strassburg, in order to become acquainted with the use of seismological instruments. Through the generosity of M. Ernest Solvay, he was enabled to construct a seismological station at the Royal Observatory of Uccle, where he installed three horizontal pendulums of the Rebeur-Ehlert type. His observations there were continued until the end of 1903, when M. Solvay presented the station to the Belgian Government. At the same time, two other stations were placed under his direction, one of them at a depth of more than half a mile in a disused passage of a coalmine, the principal object of which was to discover if any relation exists between microseismic movements and the emission of firedamp. From 1908, Prof. Lagrange directed the wellknown journal Ciel et Terre, until, in 1910, it was combined with the Bulletin de la Société belge d'Astronomie. 